\title{
Quantitative Genetic Variation in Carbonic Anhydrase Isozymes from Tissues of the Pig-Tailed Macaque, Macaca nemestrina
}

\author{
Verle E. Headings ${ }^{1,2}$ and Richard E. Tashian ${ }^{1}$
}

Received 17 Dec. 1970-Final 8 Feb. 1971

Two isozymes of carbonic anhydrase (CA I and CA II) were quantified by a radioimmunoassay in 10 different tissues of the pig-tailed macaque. There were clearly differences in relative amounts of the two isozymes, indicating a differential regulation of these two different gene products. An inherited deficiency variant reduced red cell CAI and CA II 5000-fold and 2.7-fold, respectively. In nine other tissues, CA I was reduced from approximately twofold to 110-fold, and CA II was essentially unchanged. The CAI in deficient red cells was immunochemically and electrophoretically identical to common electrophoretic variants of $C A I$ in the pig-tailed macaque and was enzymatically active.

\section{INTRODUCTION}

The quantity of carbonic anhydrase in certain tissues appears to be subject to both physiological and genetic variables. Large quantitative differences among tissues have been shown to occur in numerous species and certain physiologic agents are known to change the quantity of the enzyme (see Maren, 1967). For example, quantitative changes in uterine endometrium of certain rodents and human subjects can be induced by progestins (Lutwak-Mann, 1955; Pincus and Bialy, 1963; Nicholls and Board, 1967). In the red cells of hyperthyroid human subjects, the quantity of one carbonic anhydrase isozyme was significantly reduced, but another genetically different carbonic anhydrase isozyme was relatively unchanged (Weatherall and McIntyre, 1967; Magid, 1970; Headings and Tashian, 1970b). Quantitative changes are also known to accompany the development of organs and red cells in primates and rodents (Clark, 1951; Berfenstam, 1952; Fisher, 1961; Weatherall and McIntyre, 1967).

This work was part of a doctoral dissertation submitted in partial fulfillment of the Doctor of Philosophy degree in the Horace H. Rackham School of Graduate Studies at The University of Michigan. Supported by NIH training grant 5-T01-GM-71-11 and NIH research grant GM-15419.

1 Department of Human Genetics, University of Michigan Medical School, Ann Arbor, Michigan.

2 Present address: Medical Genetics Unit, Howard University College of Medicine, Washington, D. C. 
In the red cells of the pig-tailed macaque (Macaca nemestrina), two genetically distinct isozymes ${ }^{3}$ of carbonic anhydrase were detected by starch gel electrophoresis and by immunochemical specificity (Tashian et al., 1971). Four electrophoretic variants of CA I segregated as alleles at the $C A I$ locus. About one third of 380 individuals examined in this fashion appeared to contain no $\mathrm{CA} I$ in their red cells, and this deficiency appears to be inherited as an autosomal recessive trait. The gene for this trait was either an allele at the $C A I$ locus or at a locus closely linked to it. There was no evident change in quantity of CA II.

The objectives of the study reported here are (1) to characterize certain molecular properties of the deficiency variant, using more sensitive techniques than previously used, (2) to quantify the relative distributions of CA I and CA II in extracts of 10 different tissues of the normal pig-tailed macaque, and (3) to determine the effect of the inherited deficiency variant on the relative proportions of the two isozymes in the various tissues.

\section{MATERIALS AND METHODS}

\section{Preparation of Carbonic Anhydrases and Antisera}

The two isozymes of carbonic anhydrase from human and rhesus macaque (Macaca mulatta) red cells were purified in three stages: precipitation of hemoglobin by chloroform and ethanol, partial purification of the supernatant on a DEAE-cellulose column, and separation of the two isozymes by starch gel electrophoresis as described elsewhere (Tashian, 1969). Antisera to purified human red cell CA I and CA II were prepared in rabbits as described by Tashian et al. (1968). There was extensive immunologic cross-reactivity between the homologous carbonic anhydrases of the Old World monkeys and man (Headings, unpublished), and the antisera for the human isozymes were found to be suitable for performing immunochemical studies on the homologous isozymes of the pig-tailed macaque.

\section{Immunochemical Techniques}

The technique for iodinating purified human CA I and CA II was the same as previously described (Headings and Tashian, 1970a). Likewise, the radioimmunoassay followed the previous description except that the total tissue extract volume in each assay tube was increased from 500 to $1000 \mu \mathrm{l}$. The immunodiffusion properties of the CA isozymes were assessed in a double immunodiffusion system consisting of wells punched in a layer of agar on glass plates (Niswander et al., 1964).

\section{Animals}

The applicability of the radioimmunoassay to nonhuman primate tissue extracts was evaluated in tissues from two rhesus macaques. The technique was then used to

${ }^{3}$ Referred to in this report as CA I and CA II (cf. Tashian, 1969) and by others as CA B and CA C (cf. Rickli et al., 1964). 
quantify the carbonic anhydrase isozymes in red cells and other tissues of the closely related pig-tailed macaque.

The data from two test groups of animals, those possessing the inherited deficiency variant and normal controls, demonstrated that for a number of tissues there was good agreement among animals within each of these groups. With rare exception, all values within a group for a given tissue could be generally classified as high, low, or intermediate. For certain tissues, the differences between groups were clearly larger than the differences between animals within a group. However, since previous data on the quantitation of CA I and CA II in human red cells have shown that there could be as much as a twofold, repeatable difference between individuals (Headings and Tashian, 1970a), it can be assumed that there could be a similarly inherent quantitative variation within these test groups of pig-tailed macaques.

\section{Preparation of Hemolysates and Tissue Extracts}

Samples of whole blood were obtained from pig-tailed macaques in a breeding colony at the University of Washington Primate Research Center. The CA I genotypes of these animals were determined in earlier pedjgree studies (Tashian et al., 1971). Brain, parotid glands, eyes, lungs, stomach, pancreas, kidneys, testes, and heparinized whole blood of five male pig-tailed macaques were purchased from the Woodard Research Corporation (Herndon, Virginia). The specimens were received in three shipments over a 6-month period, first from a single individual possessing the quantitative variant, followed by two pairs of variant and control animals. The organs were placed in jars containing physiologically balanced salt solution, packed in wet ice, and shipped by air. They were received within $24 \mathrm{hr}$ and processed, utilizing in part the methods outlined by Wistrand and Rao (1968).

The buffy coat along with some red cells was separated from the packed red cells by aspiration. The packed red cells were washed three times with physiological saline, and hemolysates were prepared by adding an equal volume of distilled water. The white cells were washed and centrifuged repeatedly and red cells removed by aspiration. The washed cells were lysed with distilled water.

Each organ was processed in such a way as to minimize connective tissue elements and contaminating red cells. Extraneous tissues, including visible blood vessels, were discarded. The kidneys and lungs were perfused with saline until the effluent was free of hemoglobin by visual inspection. The kidneys were then bisected and the medullas enucleated and discarded. The hilar portions of the lungs were discarded, and only peripheral portions relatively free of red cells were retained. The muscularis of the stomach wall was stripped from the mucosa and discarded. In the case of brain, relatively thin slices were taken from the surface of the cortex, minimizing the amount of white matter included in the sample to be studied. All tissues except lens were diced and washed in repeated changes of saline over a $2-3 \mathrm{hr}$ period at $5 \mathrm{C}$. The capsule was stripped from the lens, and the intact lens was washed for $5 \mathrm{~min}$ in cold saline. The tissues were blotted and stored at $-20 \mathrm{C}$ in graduated cylinders.

The tissues from the shipments of paired animals were assayed in parallel. Just prior to use, two or three tissues from each animal were thawed and a measured 
volume of PBS-BSA ${ }^{4}$ was added to the tissues in the graduated cylinders. The combined tissue and buffer volumes were recorded and the tissues homogenized under ice in a Kontes homogenizer using a motor-driven pestle. Tissues containing relatively dense connective tissue, such as in parotid gland and lung, were not completely homogenized by this procedure; however, freezing and thawing combined with the vigorous treatment in the homogenizer almost certainly lysed the majority of cells. Even in the event of incomplete lysis, the major objectives of this study would not be altered since the ratio of CA II to CA I in the various organs was of primary interest.

The homogenates and lysates were centrifuged at $34,000 \times g$ and the supernatants were recentrifuged at $100,000 \times g$ for $60 \mathrm{~min}$ at $5 \mathrm{C}$ in a Beckman Model $\mathrm{L}$ ultracentrifuge. Parotid gland was not cleared at this speed and was therefore centrifuged at $150,000 \times g$. It has been reported that certain subcellular fractions may be associated with differing quantities of carbonic anhydrase (Maren et al., 1966; Maren and Ellison, 1967). The present study was confined to the soluble cell fraction. Total protein in the clear supernatants was determined by the method of Lowry et al. (1951) and dilution series were prepared for quantifying CA I and CA II by the radioimmunoassay.

Lung and kidney cortex unavoidably contained small amounts of contaminating red cells, and an attempt was made to correct for the CA I and CA II which such cells would contribute to the tissue preparations. This was done by measuring hemoglobin spectrophotometrically at $540 \mathrm{~m} \mu$ in tissue supernatants and in hemolysate (Drabkin, 1945) and then computing the quantities of CA I and CA II per unit of hemoglobin in the hemolysate. However, it was found that the levels of hemoglobin in the supernatants were too low to be useful in estimating the extent of contamination.

\section{RESULTS}

\section{Reliability of the Radioimmunoassay}

Purified red cell CA I and CA II from rhesus macaques were used for quantifying the pig-tailed macaque enzymes. These two species have been classified in the same genus, and their homologous carbonic anhydrases proved to be immunochemically indistinguishable both by the immunodiffusion test and by the radioimmunoassay. Figures 1 and 2 show representative dose-response curves for CA I and CA II purified from rhesus red cells and in hemolysate and tissue extracts from the pig-tailed macaque. These curves were essentially parallel throughout their linear portions except for a number of pancreas extracts. The purified rhesus isozymes were therefore considered adequate as standards for quantifying the homologous enzymes of the pig-tailed macaque and were used as such throughout the entire study.

\section{Quantitative Deficiency in Red Cell CA I and CA II}

The inherited deficiency variant of CA I appeared to represent a complete absence of the enzyme as tested by the zymogram technique and by double immunodiffusion

\footnotetext{
${ }^{4}$ Phosphate-buffered saline containing crystallized bovine serum albumin $(0.14 \mathrm{M} \mathrm{NaCl}, 0.01 \mathrm{M}$ sodium phosphate, $0.1 \%$ bovine serum albumin, $p \mathrm{H} 7.0$ ).
} 
CA I

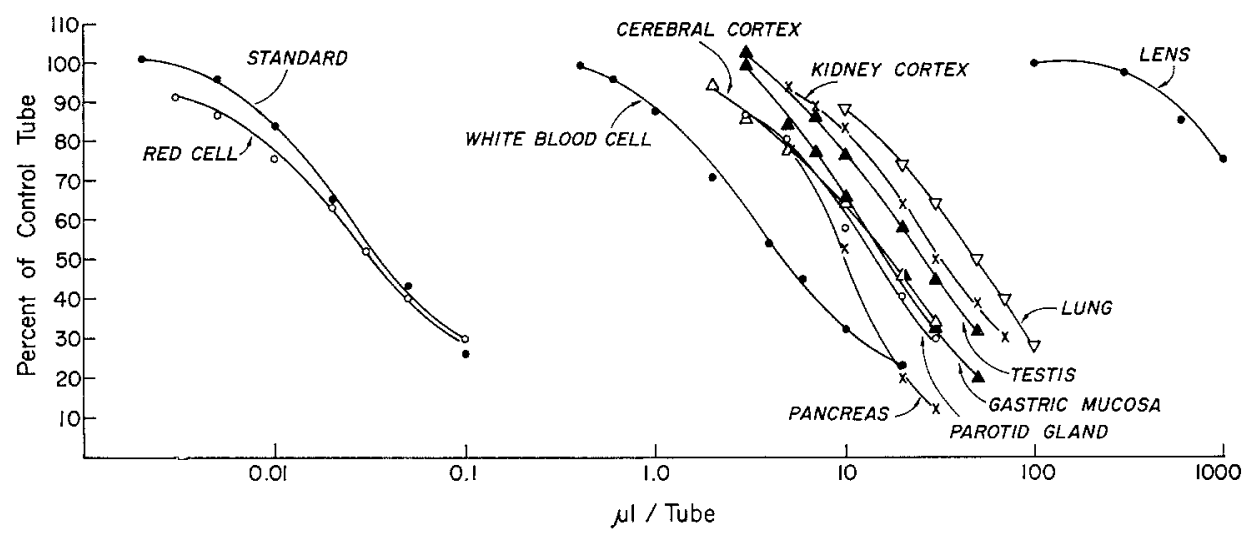

Fig. 1. Representative dose-response curves for CA I in extracts of tissues from the pig-tailed macaque. All curves shown were obtained with extracts from the same individual in the control class. The standard curve was obtained with purified red cell CA I from the rhesus macaque.

studies (Tashian et al., 1971). The sensitive radioimmunoassay, however, detected low levels of CA I as well as a moderate reduction in CA II. Fresh hemolysates from three genotypic classes of animals were tested: homozygous deficient $(o / o)$, presumed heterozygous deficient $(b / o)$, and controls (Table I). The mean quantities of CA I and CA II in fresh deficient hemolysates were reduced, respectively, 5000-fold and 2.7-fold from the control levels. The average quantity of CA I in fresh hemolysates of the heterozygous deficient genotype (i.e., b/o) was 72 percent of that in the control. Three

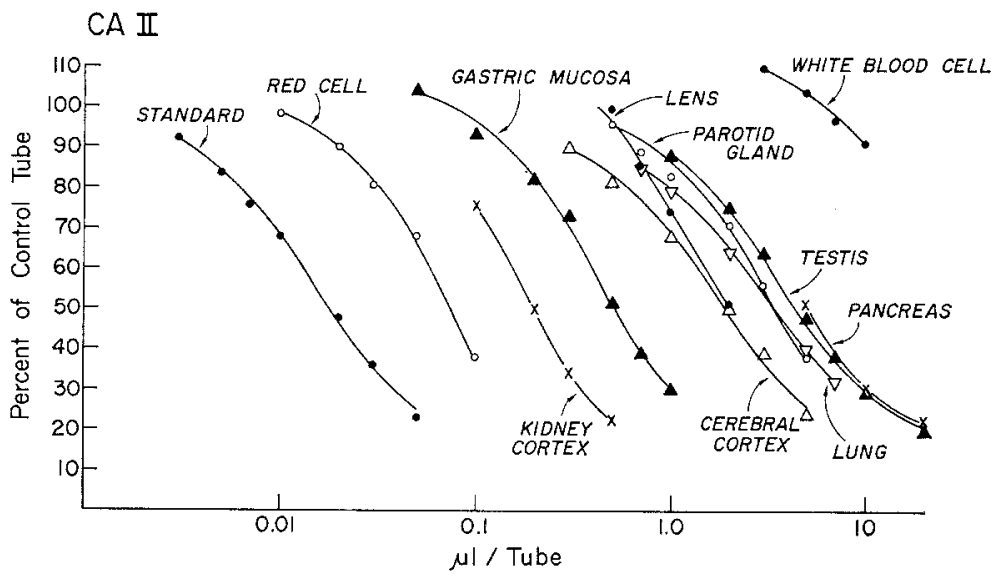

Fig. 2. Representative dose-response curves for CA II in extracts of tissues from the pig-tailed macaque. All curves shown were obtained with extracts from the same individual in the control class. The standard curve was obtained with purified red cell CA II from the rhesus macaque. 
earlier experiments on hemolysates which were stored frozen for 6-12 months gave average values of 69,57 , and 65 percent. It appeared that CA I in the red cells of the deficient heterozygote was reduced by approximately one third; however, considerable variability between animals made it impossible to identify the individual heterozygote on this basis.

\section{Immunochemical and Electrophoretic Properties of the Deficiency Variant}

Approximately $300 \mathrm{ml}$ of hemolysate pooled from 18 individuals who were homozygous for the deficiency (individual quantities ranging from 3.5 to $44 \mathrm{ml}$ ) was partially purified through precipitating the hemoglobin by chloroform and ethanol treatment. Each hemolysate sample was examined twice by the zymogram method and once by immunodiffusion to verify its deficient status before adding it to the pool. The partially purified preparation was dialyzed in $0.003 \mathrm{M}$ phosphate buffer and concentrated approximately 450 -fold from the starting hemolysate volume. In a second experiment, this procedure was followed with a similar volume of hemolysate obtained by exsanguinating a single individual possessing the deficiency variant. These concentrates were examined by the radioimmunoassay, immunodiffusion, and starch gel electrophoresis.

In Table II are shown the quantities of CA I and CA II by assay in both the starting hemolysates and the concentrated extracts from CA I-deficient animals. Of particular note is the increase in CA I antigen concentration in the concentrates.

Table I. Quantitation of Red Cell CA I and CA II in 12 PigTailed Macaques ${ }^{a}$

\begin{tabular}{|c|c|c|c|c|c|}
\hline Individual & $\begin{array}{c}\text { Presumed } \\
\text { genotype } \\
\text { CA I }\end{array}$ & CA I & Mean & CA II & Mean \\
\hline 1 & $a / b$ & 1510 & & 340 & \\
\hline 2 & $a / b$ & 850 & & 400 & \\
\hline 3 & $b / c$ & 2270 & & 380 & \\
\hline 4 & $b / b$ or $b / o$ & 1360 & 1498 & 280 & 350 \\
\hline 5 & b/o & 800 & & 300 & \\
\hline 6 & b/o & 1230 & & 410 & \\
\hline 7 & $b / o$ & 1220 & 1080 & 300 & 340 \\
\hline 8 & $o / o$ & 0.27 & & 110 & \\
\hline 9 & olo & 0.35 & & 140 & \\
\hline 10 & $o / o$ & 0.48 & & 155 & \\
\hline 11 & olo & 0.35 & & 110 & \\
\hline 12 & o/o & 0.06 & 0.30 & 132 & 130 \\
\hline
\end{tabular}

\footnotetext{
${ }^{a}$ Values are in $\mu \mathrm{g} / \mathrm{ml}$ of hemolysate. Some samples were obtained from individuals whose CA I genotype had been determined in an earlier pedigree study (Tashian et al., 1971). Additional samples were obtained along with tissues from the Woodard Research Corporation.
} 
Table II. Effect of Concentration on CA I and CA II from Hemolysates of CA I-Deficient Macaca nemestrina ${ }^{a}$

\begin{tabular}{cccccc}
\hline & \multicolumn{2}{c}{ CA I } & & \multicolumn{2}{c}{ CA II } \\
\cline { 2 - 3 } \cline { 5 - 6 } \cline { 5 - 6 } Experiment No. & Hemolysate & $\begin{array}{c}\text { Concentrated } \\
\text { extract }\end{array}$ & & Hemolysate & $\begin{array}{c}\text { Concentrated } \\
\text { extract }\end{array}$ \\
\hline 1 & 0.24 & 58 & & 170 & 44,900 \\
2 & 0.06 & 7.4 & & 130 & 38,800 \\
\hline
\end{tabular}

${ }^{a}$ Values are in $\mu \mathrm{g} / \mathrm{ml}$ hemolysate or extract.

Double immunodiffusion of the deficiency variant hemolysate did not detect CA I antigen; however, the concentrated preparation produced an immunoprecipitin band which showed complete identity with CA I of a control hemolysate (Fig. 3). Starch gel

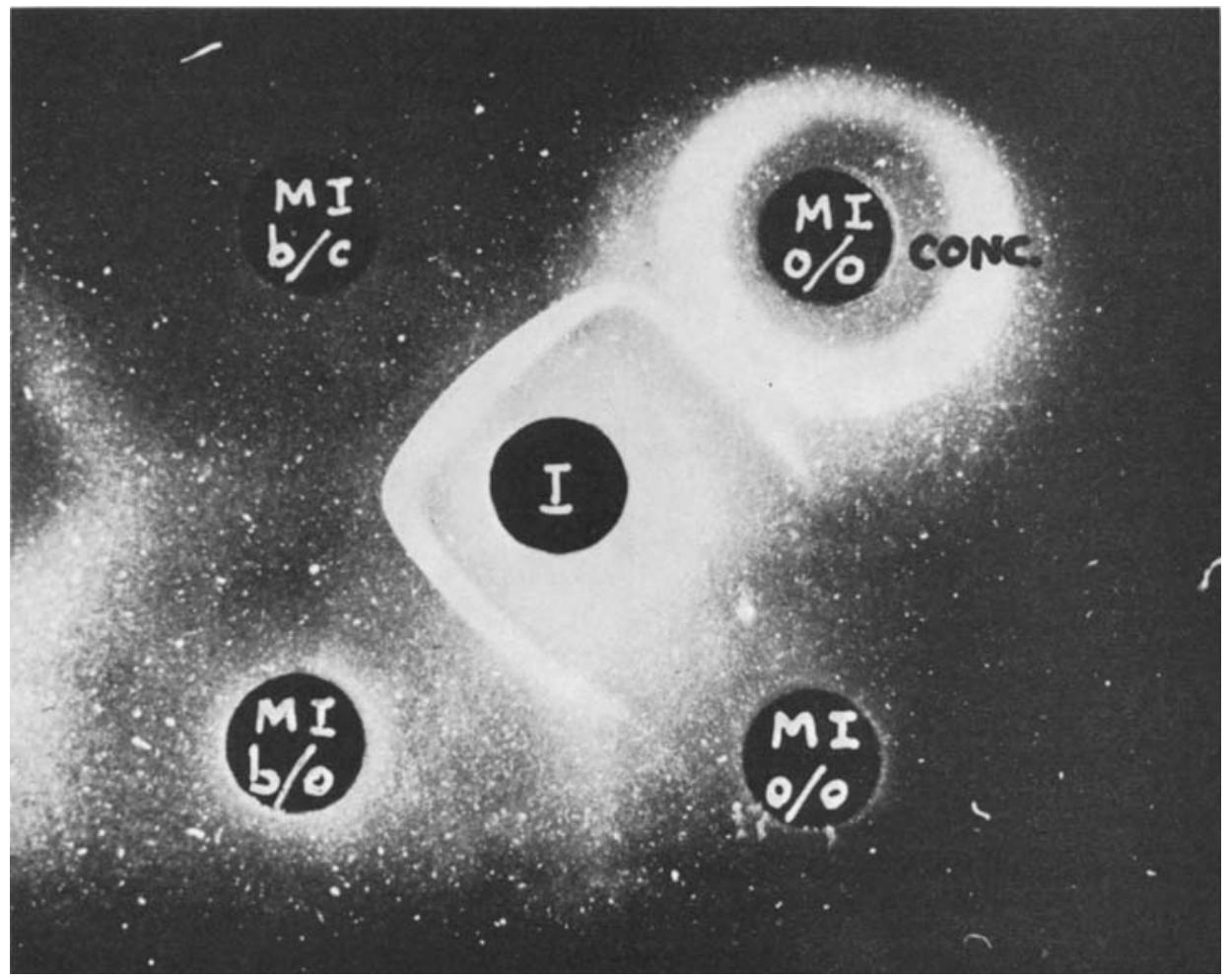

Fig. 3. Immunodiffusion reaction pattern between anti-human red cell CA I serum and red cell CA I from pig-tailed macaques. The center well contained anti-CA I serum and each of three outer wells contained hemolysate from individuals of a different CA I genotype $(b / c, b / o, o / o)$. The fourth well contained partially purified and concentrated carbonic anhydrase from type o hemolysate. 
electrophoresis of deficient hemolysates failed to show zones of esterase activity. The concentrates of both experiments, however, yielded a zone of activity which had a mobility identical to that of a common electrophoretic variant, CA Ia (Fig. 4). This zone was sensitive to acetazolamide, a specific inhibitor of carbonic anhydrase. When the gel was stained with a mixture of substrates, the staining color was typical for CA I (pink), showing an affinity for the substrate $\beta$-naphthyl acetate, in contrast to the color characteristic for zones of CA II activity (gray), showing an affinity for the substrate $\alpha$-naphthyl acetate. In this study, only the CA Ia variant was identified in

\section{ESTERASE STAIN}

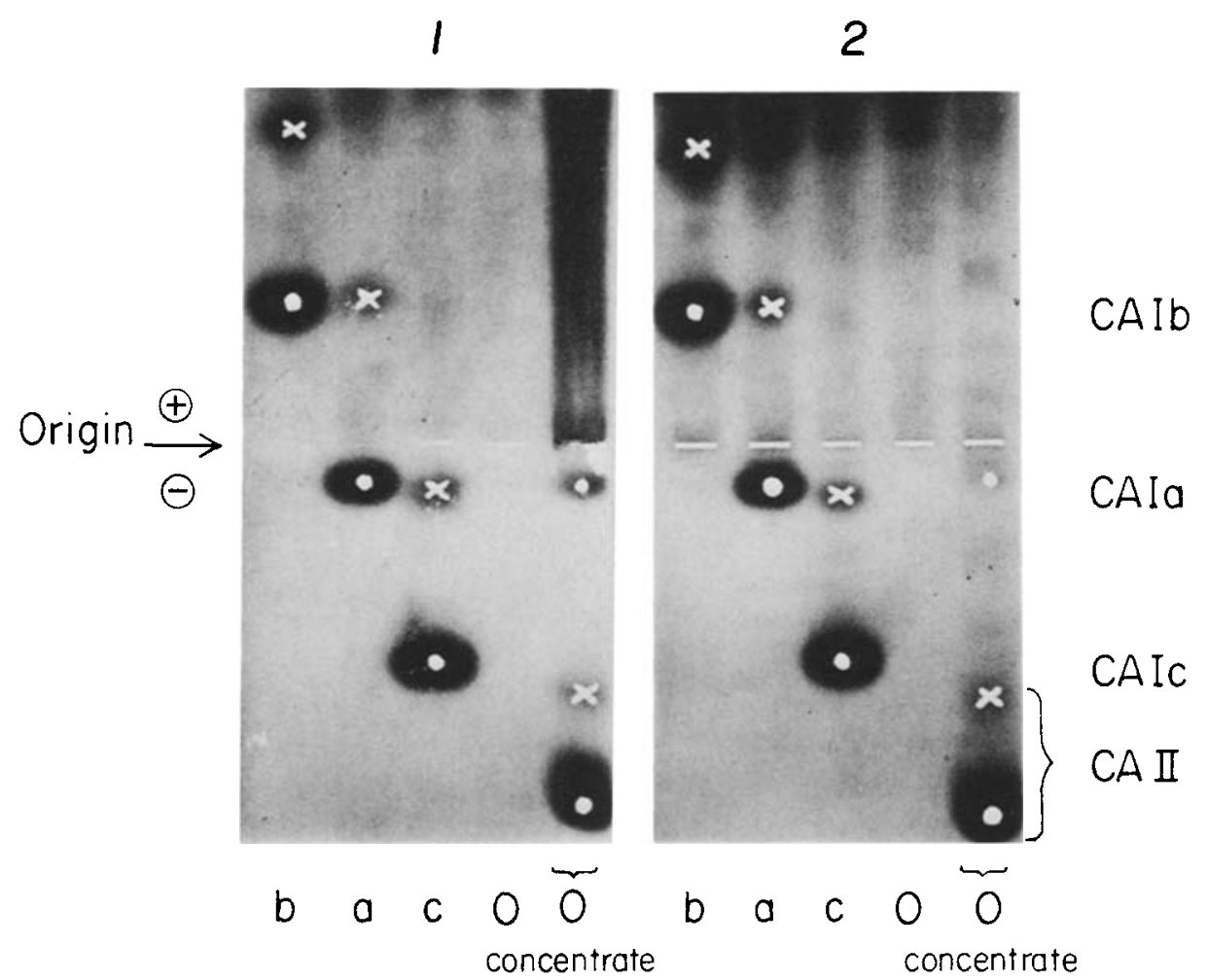

Fig. 4. Electrophoretic patterns for red cell CA I variants. Zones of enzyme activity were detected by staining for esterase activity. The genetic variants of CA I (b, a, c, and o) in hemolysates from pig-tailed macaques were compared with the o variant in a partially purified and concentrated preparation. The dots and crossmarks, respectively, identify the major and minor forms of the variants. All marked zones were inhibited by acetazolamide. Zones of CA II from hemolysates frequently were not detected on the basis of esterase activity; however, in the type o concentrates a major and minor zone were present. These were identified as CA II by their staining properties (gray) and their reactivity with anti-CA II serum in an immunodiffusion system. A zone of activity with a staining color characteristic for CA I (pink) and a mobility identical with CA Ia was observed in two different concentrated preparations of the type o variant $(1$ and 2 ). 
CA I-deficient individuals; however, in other studies the CA Ib variant was identified as well in certain CA I-deficient individuals (see Tashian et al., 1971).

\section{Distributions of CA I and CA II Among Tissues}

CA I and CA II were quantified in extracts of 10 different tissues from two pig-tailed macaques whose red cell CA I types were bc and $b$. The data from these animals served as a control for those from individuals possessing the deficiency variant. On the basis of micrograms of CA per milliliter of combined buffer and tissue volume (Table III), the following pattern of values was observed: In seven tissues, the mean CA I values clustered between about 3 and 5 ; in one (lens) it was 0.1 , and in white cell and red cell it was 16.5 and 1815 , respectively. For CA II, the values ranged from 1.4 to 330.

CA I and CA II were also assayed in 10 different tissues of three pig-tailed macaques possessing the deficiency variant. CA I was distributed among the tissues in quantities between $0.031-0.71 \mu \mathrm{g}$ per milliliter of combined buffer and tissue volume and CA II between 2.8 and 132 (Table III).

\section{Quantitative Relationships Between CA I and CA II}

Analyses of the isozyme distributions included comparisons of CA I and CA II in CA I-deficient and normal pig-tailed macaques (Table III). The highest CA II/CA I ratio (1100) in the normal control group was found in the lens; in all other tissues, this ratio was below 30 . In all tissues tested, except red cell (0.2) and white cell (0.09), CA II was essentially equal to or greater than CA I. Red cells contained about five times more CA I than CA II; therefore, if red cell contamination was a major contributor to the ratios in tissues other than red cells, the latter should have approximated the red cell ratio. Such similarity occurred only in the white cell extracts. The quantities of CA I and CA II shown in Table III indicated that in gastric mucosa, parotid gland, pancreas, lung, testis, cerebral cortex, and kidney cortex the mean CA I values were more similar to one another than were the CA II values. Therefore, intertissue differences in CA II/CA I ratios are primarily a function of variability in CA II. This analysis of the CA II/CA I ratios indicates that these two gene products are differentially controlled in the various tissues of the control animals.

The CA II/CA I ratios in tissues of animals possessing the deficiency variant followed a decidedly different distribution than in the controls (Table III). Intertissue variability in the overall effect of the mutation on the CA II/CA I ratio was examined by contrasting the two sets of ratios. The differences ranged from virtually no change in the lens to more than 2000-fold change in the red cell. In relation to the discussion in the preceding paragraph, it is significant that even though the CA II/ CA I ratios of red cell and white cell (i.e., 0.2 and 0.09 , respectively) were similar in control animals they clearly differed in animals possessing the deficiency variant (440 and 22, respectively). More detailed information on the effect of the mutation was obtained by examining differences for CA I and CA II, respectively, between CA I-deficient and normal animals. The mean values for each tissue were converted to a ratio of normal 


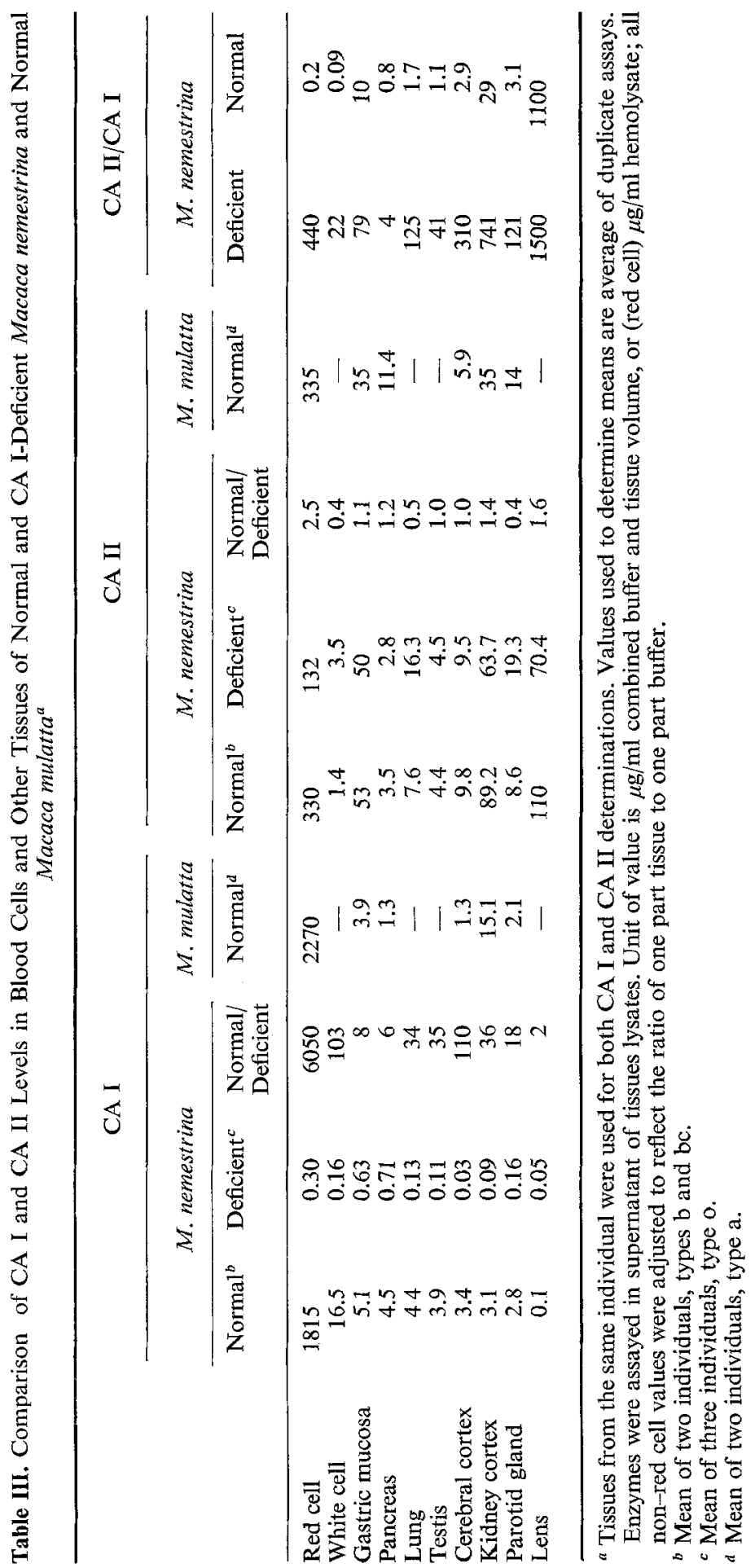


to deficient (Table III). The deficiency gene in the homozygous state was associated with approximately a 6000-fold reduction in red cell CA I. Reductions of twofold to 110 -fold occurred in the nine other tissues. The wide range of this ratio suggested that the quantities of CA I were disproportionately reduced in the 10 tissues tested. It also appeared that the quantities of CA I were not reduced to a common level among all 10 tissues, since there was about a 20 -fold difference between the two extreme mean values (Table III).

The effect of the deficiency gene on CA II was evident primarily in the red cell, which showed a 2.5 -fold reduction. It is particularly noteworthy that there was no similar reduction in white cell CA II.

\section{DISCUSSION AND SUMMARY}

Previous studies on the kinetic and inhibition characteristics of carbonic anhydrase in tissues other than blood have been based on total enzyme activity measurements (cf. Maren, 1967). From such studies it was assumed that the predominant isozyme in most non-red cell tissues is CA II. These measurements did not, however, allow reliable estimates of relative differences in quantity of the two gene products, which are necessary for a study of regulatory processes.

The carbonic anhydrase isozymes of pig-tailed macaques are a particularly advantageous system in which to investigate mechanisms of gene regulation. The two isozymes are each single polypeptide chains and are the products of different genetic loci. They are both widely distributed among tissues and their quantities appear to vary independently. The deficiency gene in homozygous state leads to about a 5000fold decrease in red cell CA I; the protein remains enzymatically active, and retains the electrophoretic mobility and immunochemical cross-reactivity of normal CA I. There appears to be approximately a one-third reduction in red cell CA I of individuals presumed on the basis of pedigree data to be heterozygous for the deficiency gene. The effect of the deficiency gene in the homozygous state on CA I is clearly different among the 10 tissues tested.

The quantity of CA II was reduced 2.7-fold in CA I-deficient red cells but not appreciably in the nine other tissues tested. Continuing investigations on the differential effect of the deficiency gene on quantities of red cell CA I and CA II may further characterize control mechanisms which these isozymes have in common.

The occurrence of differences in the relative amount of the two isozymes among tissues in itself suggests that the two are subject to different regulatory factors. Superimposed on this, the deficiency mutation appears to exert an incomplete and variable restriction on the quantity of CA I. This set of findings, along with the genetic data on the deficiency variant (Tashian et al., 1971), is not inconsistent with the concept of a type of genetic regulator locus for CA I. Continuing studies are designed to test this possibility more specifically.

The functional significance of differences in the quantity of carbonic anhydrase among tissues is unclear. Certainly some red cell enzyme is essential for liberating the required amount of $\mathrm{CO}_{2}$ during one passage of blood through the lungs. Studies on a number of tissues have indicated, however, that many tissues contain approximately a 
1000-fold excess of carbonic anhydrase activity (see Maren, 1963). Gibbons and Edsall (1964) obtained a CA II/CA I hydrase activity ratio of 30 for the purified human red cell isozymes, using approximately physiological assay conditions. There is reason to believe that a similar activity ratio exists for the red cell isozymes of the pig-tailed macaque. Assuming this activity ratio, the calculated total hydrase activity in red cells containing the deficiency variant was 34 percent of the control level. It seems highly improbable that the decrease in total enzyme activity is physiologically significant in terms of hydrase activity in vivo.

\section{ACKNOWLEDGMENTS}

We gratefully acknowledge the excellent research assistance of the late Mr. Arthur A. Smiltens. We also wish to thank Dr. A. Rees Midgley, Dr. George Nace, and Dr. Donald C. Shreffler for their useful suggestions during this study.

\section{REFERENCES}

Berfenstam, R. (1952). Carbonic anhydrase activity in fetal organs. Acta Paediat. 41 : 310.

Clark, A. M. (1951). Carbonic anhydrase during embryonic development. J. Exptl. Biol. $28: 332$.

Drabkin, D. L. (1945). Crystallographic and optical properties of human hemoglobin. A proposal for the standardization of hemoglobin. Am. J. Med. Sci. 209: 268.

Fisher, D. A. (1961). Carbonic anhydrase in fetal and young rhesus monkeys. Proc. Soc. Exptl. Biol. Med. 107: 359.

Gibbons, B. H., and Edsall, J. T. (1964). Kinetic studies of carbonic anhydrases B and C. J. Biol. Chem. 239: 2539.

Headings, V. E., and Tashian, R. E. (1970a). A radioimmunoassay for quantifying carbonic anhydrase isozymes in crude lysates. Biochem. Genet. 4: 285.

Headings, V. E., and Tashian, R. E. $(1970 \mathrm{~b})$. Differential inhibition of red cell carbonic anhydrase isozymes in hyperthyroidism. Nature 228: 1197.

Lowry, O. H., Rosebrough, N. J., Farr, A. L., and Randall, R. J. (1951). Protein measurement with the Folin phenol reagent. J. Biol. Chem. 193: 265.

Lutwak-Mann, C. (1955). Carbonic anhydrase in the female reproductive tract. Occurrence, distribution and hormonal dependence. J. Endocrinol. 13: 26.

Magid, E. (1970). Erythrocyte carbonic anhydrase B levels in thyroid disorders. Lancet 1: 1342.

Maren, T. (1963). The relation between enzyme inhibition and physiological response in the carbonic anhydrase system. J. Pharmacol. Exptl. Therap. 139: 140.

Maren, T. (1967). Carbonic anhydrase: Chemistry, physiology and inhibition. Physiol, Rev. 47: 595.

Maren, T., and Ellison, A. (1967). A study of renal carbonic anhydrase. Mol. Pharmacol. 3: 503.

Maren, T., Ellison, A., Fellner, S., and Graham, W. (1966). A study of hepatic carbonic anhydrase. Mol. Pharmacol. $2: 144$.

Nicholls, R., and Board, J. (1967). Carbonic anhydrase concentration in endometrium after oral progestins. Am. J. Obstet. Gynecol. 99: 829.

Niswander, J. D., Shreffler, D. C., and Neel, J. V. (1964). Genetic studies of quantitative variation in a component of human saliva. Ann. Human Genet. 27: 319.

Pincus, G., and Bialy, G. (1963). Carbonic anhydrase in steroid-responsive tissues Recent Progr. Hormone Res. 19: 201.

Rickli, E. E., Ghazanfar, S. A. S., Gibbon, B. H., and Edsall, J. T. (1964). Carbonic anhydrase from erythrocytes; preparation and properties of two enzymes. J. Biol. Chem. 239: 1065.

Tashian, R. E. (1969). The esterases and carbonic anhydrases of human erythrocytes. In Yunis, J. (ed.), Biochemical Methods in Red Cell Genetics, Academic Press, New York, pp. 307336. 
Tashian, R. E., Shreffler, D. C., and Shows, T. B. (1968). Genetic and phylogenetic variation in the different molecular forms of mammalian erythrocyte carbonic anhydrases. Ann. N.Y. Acad. Sci. 151: 64 .

Tashian, R. E., Goodman, M., Headings, V. E., DeSimone, J., and Ward, R. H. (1971). Genetic variation and evolution in the red cell carbonic anhydrase isozymes of macaque monkeys. Biochem. Genet. 5: 183.

Weatherall, D. J., and McIntyre, P. A. (1967). Developmental and acquired variations in erythrocyte carbonic anhydrase isozymes. Brit. J. Haematol. 13: 106.

Wistrand, P. J., and Rao, S. N. (1968). Immunologic and kinetic properties of carbonic anhydrases from various tissues. Biochim. Biophys. Acta 154: 130 . 